\title{
Homeostatic regulation in a single neuron model from the Pre-Bötzinger Complex
}

\author{
Max F Oginsky ${ }^{1 *}$, Gennady S Cymbalyuk ${ }^{2}$
}

From Twenty First Annual Computational Neuroscience Meeting: CNS*2012

Decatur, GA, USA. 21-26 July 2012

Central Pattern Generators (CPGs) control rhythmic movements in diverse species ranging from decapods to mammals. For the same CPG, from preparation to preparation, the intrinsic membrane properties of CPG neurons are highly disparate and modulated, however the network output remains constant. This leads to questions regarding the coregulation of currents preserving essential dynamics of a neuron. When the fasttransient potassium current, $\mathrm{I}_{\mathrm{A}}$, is increased in the pyloric dilator neuron of the stomatogastric ganglion, there is a compensatory increase in the hyperpolarization-activated current, $\mathrm{I}_{\mathrm{H}}[1]$. This prevents changes in the output

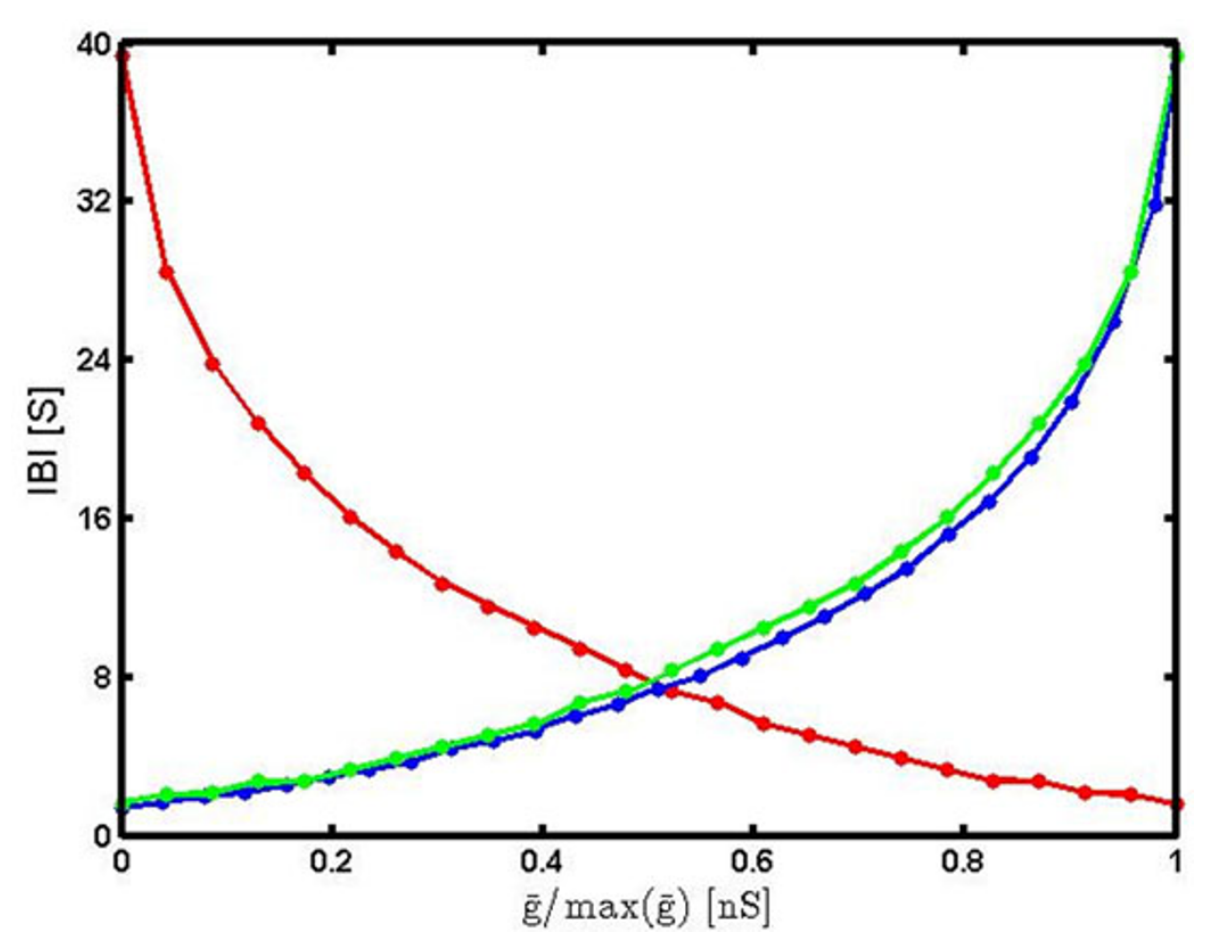

Figure 1 Dependence of interburst interval on $\overline{\mathbf{g}}_{A}$ (blue) and $\overline{\mathbf{g}}_{A}\left(\right.$ red). Conductances were normalized to their maxima, $\max \left(\overline{\mathbf{g}}_{A}\right)$ and $\max \left(\overline{\mathbf{g}}_{H}\right)$. Green curve represents the IBI dependence on $\left(1-\frac{\bar{g}_{H}}{\max \left(\bar{g}_{H}\right)}\right)$

'Department of Biology, Georgia State University, Atlanta, GA 30303, USA

Full list of author information is available at the end of the article 
of this well-studied CPG. Here, we test whether this coregulation would be effective if applied to the dynamics of another well-studied CPG found in mammals that controls breathing. We hypothesized that when the maximal conductance, $\overline{\mathrm{g}}_{A}$, of $\mathrm{I}_{\mathrm{A}}$ was increased there would be an increase in the period and interburst interval (IBI) and subsequently increasing the maximal conductance, $\overline{\mathrm{g}}_{H}$, of $\mathrm{I}_{\mathrm{H}}$ would provide a matching compensatory decrease. To investigate this, we modified a single neuron model of the pre-Bötzinger complex [2] by adding $\mathrm{I}_{\mathrm{A}}[3]$ and $\mathrm{I}_{\mathrm{H}}[4]$. We investigated this model by systematically exploring properties of the ionic currents.

First, we increased $\bar{g}_{A}$ from 0 to $51 \mathrm{nS}$. This increased the period and IBI from $1.78 \mathrm{~s}$ to $40.12 \mathrm{~s}$ and $1.37 \mathrm{~s}$ to $39.35 \mathrm{~s}$, respectively (Fig. 1, blue curve). At the same time, the spike frequency and spike number increased from 10.29 to $60.72 \mathrm{~Hz}$ and 5.00 to 38.35 spikes, respectively. Then we subsequently increased $\overline{\mathrm{g}}_{H}$ from $0 \mathrm{nS}$ to $69 \mathrm{nS}$. The period and IBI was decreased from $40.12 \mathrm{~s}$ to $2.02 \mathrm{~s}$ and 39.35 to $1.64 \mathrm{~s}$, respectively (Fig. 1, red curve). The spike frequency and spike number decreased from 60.72 to $13.93 \mathrm{~Hz}$ and 36.50 to 2.74 spikes, respectively. In Figure 1 we presented the data for the IBIs. To place the graphs on the same scale we normalized the parameter values by the maximum values used in the study. The blue and red curves look similar, except $\bar{g}_{A}$ graph grows and $\overline{\mathrm{g}}_{H}$ graph decays. To further evaluate how well the two dependences are matched, we plotted the IBI dependence on $\left(1-\frac{\bar{g}_{H}}{\max \left(\bar{g}_{H}\right)}\right)$ as the green curve. One could see that the green and blue curves are well matched.

This model shows that increasing $\mathrm{I}_{\mathrm{H}}$ opposes the effects of increasing $I_{A}$ in period, IBI, frequency and spike number. This may be a common mechanism for regulating rhythmic patterns in CPGs.

\section{Acknowledgements}

This research was supported by NSF grant PHY-0750456 to GC.

\section{Author details}

'Department of Biology, Georgia State University, Atlanta, GA 30303, USA

${ }^{2}$ Neuroscience Institute, Georgia State University, Atlanta, GA 30303, USA.

Published: 16 July 2012

\section{References}

1. MacLean JN, Zhang Y, Goeritz ML, Casey R, Oliva R, Guckenheimer J, HarrisWarrick RM: Activity-independent coregulation of $\mathrm{IA}$ and $\mathrm{Ih}$ in rhythmically active neurons. J Neurophysiol 2005, 94(5):3601-3617.

2. Rybak IA, Shevtsova NA, St-John WM, Paton JF, Pierrefiche O: Endogenous rhythm generation in the pre-Botzinger complex and ionic currents: modelling and in vitro studies. Eur J Neurosci 2003, 18(2):239-257.

3. Hayes JA, Mendenhall JL, Brush BR, Del Negro CA: 4-Aminopyridinesensitive outward currents in preBotzinger complex neurons influence respiratory rhythm generation in neonatal mice. J Physiol 2008, 586(7):1921-1936.

4. Thoby-Brisson M, Cauli B, Champagnat J, Fortin G, Katz DM: Expression of functional tyrosine kinase $B$ receptors by rhythmically active respiratory neurons in the pre-Botzinger complex of neonatal mice. J Neurosci 2003, 23(20):7685-7689.

doi:10.1186/1471-2202-13-S1-P158

Cite this article as: Oginsky and Cymbalyuk: Homeostatic regulation in a single neuron model from the Pre-Bötzinger Complex. BMC Neuroscience 2012 13(Suppl 1):P158.

\section{Submit your next manuscript to BioMed Central and take full advantage of:}

- Convenient online submission

- Thorough peer review

- No space constraints or color figure charges

- Immediate publication on acceptance

- Inclusion in PubMed, CAS, Scopus and Google Scholar

- Research which is freely available for redistribution 